\title{
Hubungan Derajat Skor CURB-65 Saat Awal Masuk dan Nilai Antitrombin III pada Pasien Pneumonia Komunitas
}

\author{
Sari Andriyani, E.N. Keliat, Alwinsyah Abidin \\ Departemen Ilmu Penyakit Dalam Fakultas Kedokteran Universitas Sumatera Utara \\ RSUP H. Adam Malik Medan
}

\begin{abstract}
Abstrak
Pada penderita pneumonia komunitas (PK) dilakukan penilaian derajat keparahan pada awal pasien masuk sangat penting sebab akan menentukan beratnya penyakit dan rencana tata laksana selanjutnya. Antitrombin III (AT-III) sebagai biomarker koagulasi berguna untuk menilai tingkat keparahan PK pada saat awal masuk. AT-III dapat berperan dalam diagnosis, memutuskan pemberian antibiotik, dan prognosis penderita PK. Penelitian ini betujuan mengetahui hubungan skor confusion, urea, respiratory rate, blood pressure, age $\geq 65$ years (CURB-65) dan nilai AT-III pada saat awal pasien PK datang ke rumah sakit. Desain penelitian adalah potong lintang. Penelitian dilakukan di Rumah Sakit H. Adam Malik Medan pada bulan Februari-Maret 2013. Subjek dengan PK yang masuk dari instalasi gawat darurat, pasien rawat jalan setelah memenuhi kriteria dilakukan penilaian skor CURB-65, laboratorium darah, serta kultur sputum dan darah. Selanjutnya, skor CURB-65 dihubungkan dengan AT-III dan parameter lainnya. Sebanyak 55 subjek penelitian yang tergolong dalam skor CURB-65 berat (3-5) sebanyak 23 orang (42\%), skor sedang (2) sebanyak 17 orang (31\%) dan skor ringan (0-1) sebanyak 15 orang (27\%). Setelah dilakukan uji korelasi Spearman diperoleh hubungan signifikan antara derajat skor CURB-65 dan nilai AT-III ( $\mathrm{p}=$ 0,0001). Simpulan, AT-III merupakan biomarker koagulasi yang memiliki hubungan dengan derajat keparahan PK yang dinilai dengan skor CURB-65 sehingga AT-III dapat digunakan untuk menentukan prognosis pasien PK sejak awal masuk rumah sakit. [MKB. 2016;48(2):92-8]
\end{abstract}

Kata kunci: Antitrombin III (AT-III), pneumonia komunitas (PK), prognosis, skor CURB-65

\section{Correlation between CURB-65 and Antithrombin III Scores in Community Acquired Pneumonia at Early Admission in Hospital}

\begin{abstract}
The assessment of the level of severity in patients with community acquired pneumonia (CAP) is very important to determine the next steps in the disease management. Antithrombin III (AT-III) is known as one of the coagulation biomarkers that may be useful for predicting the severity of CAP at early admission in hospital. The AT-III is known to be used in diagnosis to help clinicians decide the antibiotic treatment to be given and to make prognosis. The aim of this cross-sectional study was to determine the correlation between confusion, urea, respiratory rate, blood pressure, age $>65$ years (CURB-65) score and AT-III in CAP patients at early admission in hospital. The method of study. The data were collected in Adam Malik Hospital from February to March 2013. CAP subjects were examined with CURB-65 score, AT-III, other laboratory assessments, sputum, and blood cultures at the early admission in the emergency room and outpatient clinic. The CURB-65 score was correlated with AT-III to determine the prognostic use of AT-III. A total of CAP 55 subjects were assessed with 23 subjects (42\%) with severe CURB-65 scores (3-5), 17 subjects (31\%) with moderate scores (2), and15 subjects (27\%) with mild scores (0-1). A significant correlation between CURB-65 and AT-III was found through the use of Spearman correlation test $(\mathrm{p}=0.0001)$. In conclusion, AT-III is a coagulation biomarker that correlates with the CURB-65 clinical scoring system. AT-III can be used to determine the prognosis in CAP at early admission in hospital. [MKB. 2016;48(2):92-8]
\end{abstract}

Key words: Antithrombin III (AT-III), community acquired pneumonia (CAP), CURB-6 score, prognosis

Korespondensi: Sari Andriyani, dr., SpPD., M.Ked (PD), Departemen Ilmu Penyakit Dalam Fakultas Kedokteran Universitas Sumatera Utara Medan/RSUP H. Adam Malik Medan, Jalan Bunga Lau No.17 Medan, mobile08126502821,e-mail sariandriyani@ ymail.com 


\section{Pendahuluan}

Pneumonia komunitas (PK) merupakan masalah utama morbiditas dan mortalitas di Amerika Serikat dan di dunia. Influenza dan pneumonia adalah penyebab utama kematian kedelapan di Amerika Serikat. Pada tahun 2011, dari data Centers for Disease Control (CDC) di Amerika Serikat terdapat sekitar 52.136 kematian itu disebabkan oleh pneumonia dengan angka kematian sekitar 16,7 per 100.000 orang. ${ }^{1}$

Di negara maju seperti Amerika Serikat, PK menyebabkan angka rawatan 1,3 juta orang per tahun dan tercatat sebagai penyebab terbesar sepsis berat dan kematian terbanyak akibat infeksi. ${ }^{2}$ Tingginya angka kejadian dan dampak mortalitas diikuti oleh biaya kesehatan yang tinggi terutama pada penderita PK berat. ${ }^{3}$

Pneumonia secara umum adalah peradangan yang mengenai parenkim paru, distal bronkiolus terminalis yang mencakup bronkiolus respiratorius dan alveoli, serta menimbulkan konsolidasi jaringan paru dan juga gangguan pertukaran gas setempat. ${ }^{4}$

Dalam hal membantu tegaknya diagnosis pneumonia, beberapa biomarker telah dikenal, seperti CRP, jumlah leukosit, imunoglobulin, PCT, dan triggering receptor expressed on myeloid cell-1 (TREM-1). Beberapa biomarker lain yang masih dalam tahap studi untuk penggunaannya pada pneumonia antara lain co-peptin, kortisol, endotoksin, dan proadrenomedulin. ${ }^{5}$

Selain petanda inflamasi, sistem koagulasi juga dikatakan memiliki potensi dalam menilai risiko kematian penderita PK. Aktifasi sistem koagulasi dan aktivitas fibrinolisis merupakan gambaran yang dijumpai pada keadaan sepsis berat. ${ }^{6,7}$

Dalam beberapa tahun terakhir berbagai studi telah mencoba meneliti dalam respons host terhadap bakteri terutama terhadap aktivasi koagulasi. Respons terhadap infeksi yang dapat memberikan dampak terhadap sistem koagulasi yang mungkin berperan adalah patogenesis disfungsi organ. Beberapa studi epidemiologi memperlihatkan bahwa gangguan yang umum pada sepsis berat akan mengaktivasikan atau menyebabkan gangguan pada sistem koagulasi. ${ }^{8}$

Pneumonia yang awalnya infeksi lokal dan mengakibatkan aktivasi koagulasi sistemik, hal ini disebabkan oleh aktivasi lokal dari sistem koagulasi yang terjadi pada pneumonia dengan deposisi fibrin dalam kompartemen alveolar yang terinfeksi, meningkatkan permeabilitas pembuluh darah, merangsang proinflamasi sitokin, dan meningkatkan akumulasi neutrofil. ${ }^{9}$
Aktivasi koagulasi lokal yang muncul akan didorong terutama oleh tissue factor. Biasanya, sangat sedikit tissue factor yang keluar dari sirkulasi darah, namun alveolar makrofag, neutrofil, dan sel endotel dapat mengeluarkan tissue factor pada permukaan serta mampu membentuk thrombogenic tissue factor yang kemudian akan berkembang menjadi gangguan koagulasi sistemik selama infeksi paru. ${ }^{10}$

Terdapat beberapa biomarker koagulasi potensial yang dapat digunakan, yaitu protein C, D-dimer atau DD, thrombin-AT-complex, prothrombin fragment 1,2, dan activated partial thromboplastin time. ${ }^{6,7}$ Penelitian yang dilakukan oleh Agapakis dkk. ${ }^{11}$ telah melaporkan bahwa antitrombin III (AT-III) merupakan biomarker koagulasi pada PK memiliki sensitivitas $80 \%$ dan spesifisitas 75\%. dengan nilai cut-off point 85\% untuk menentukan perlunya perawatan di rumah sakit. Pada studi yang dilakukan Agapakis dkk. ${ }^{11}$ dengan mengukur nilai AT-III serum saat masuk tampaknya berguna untuk menilai tingkat keparahan PK dan dapat menjadi biomarker untuk mendukung keputusan pada pasien dengan PK.

AT-III pada keadaan sepsis, endotoksin yang dihasilkan oleh bakteri menstimulasi sitokin proinflamasi. Endotoksin yang menstimulasi sitokin proinflamasi menyebabkan kerusakan langsung pada endotel, menginduksi adhesi leukosit ke sel endotel dan juga produksi nitric oxide, serta mengaktifkan komplemen dan jalur koagulasi. Aktivasi jalur koagulasi ini berkaitan dengan terjadinya kerusakan endotel, bekuan intravaskular dan juga trombosis mikrovaskular, serta terjadi konsumsi faktor antikoagulan alami seperti AT-III, protein C, dan protein S. ${ }^{12}$

Dari penelitian Fourrier dkk. ${ }^{13}$ didapatkan bahwa secara signifikan nilai AT-III rendah pada pasien sepsis baik yang hidup dengan persentase $(61 \pm 3)$ maupun yang tidak hidup $(35 \pm 2)(\mathrm{p}<0.0001)$.

Penelitian Pettila dkk. ${ }^{14}$ juga menunjukkan bahwa nilai AT-III yang rendah pada pasien sepsis antara pasien yang hidup (66\%) maupun yang tidak hidup $(46 \%)$ secara signifikan $(\mathrm{p}<0.001)$. Penelitian yang dilakukan oleh Asfhari dkk. ${ }^{15}$ disimpulkan bahwa penurunan konsentrasi nilai AT-III sekitar 20-40\% pada keadaaan sepsis ini sejalan dengan berat keparahan penyakit. ${ }^{15}$

Berbagai sistem untuk memeriksa keparahan penyakit dan risiko kematian pada PK telah ada dan dipakai secara luas, antara lain Pneumonia Severity Index (PSI), Patients Outcomes Research Team Score (PORT), skor confusion, urea, respiratory rate, blood pressure, age $\geq 65$ years 


\section{(CURB-65). ${ }^{6,7}$}

Derajat keparahan PK dinilai berdasarkan skor CURB-65 seperti terlihat pada uraian di bawah ini:

Konfusio/confusion: gangguan kesadaran yang baru terjadi atau abnormalitas skor mental. Urea: $>7 \mathrm{mmol} / \mathrm{L}$; $>20 \mathrm{mg} / \mathrm{dL}$. Laju pernapasan/ respiratory rate: $\geq 30 \mathrm{x} /$ menit. Tekanan darah/ blood pressure: tekanan darah (sistol $\leq 90 \mathrm{mmHg}$ dan diastol $\leq 60 \mathrm{mmHg}$ ). Usia/age $\geq 65$ tahun

Rentang nilai pada skor di atas adalah $0-5$, setiap kriteria bernilai satu. Skor 0-1 masuk kategori risiko rendah, skor 2 kategori risiko sedang, dan skor $\geq 3$ risiko tinggi. ${ }^{6.7}$

Meskipun sistem untuk memeriksa keparahan penyakit dan risiko kematian pada PK telah ada dan dipakai secara luas seperti PSI, PORT, namun sistem tersebut terlalu rumit untuk digunakan dalam praktik sehari-hari sehingga diperlukan biomarker yang potensial dapat memberikan informasi mengenai prognosis yang setara dengan sistem skoring yang telah ada. ${ }^{2,7}$

Tujuan penelitian ini adalah mengetahui hubungan antara skor CURB-65 dan nilai AT-III pada awal pasien PK datang ke rumah sakit.

\section{Metode}

Penelitian ini dilakukan menggunakan desain potong lintang. Dilakukan di Instalasi Gawat Darurat, Ruang Rawat Inap, serta Poliklinik Pulmonologi dan Alergi Imunologi RS H. Adam Malik Medan pada bulan Februari-Maret 2013 setelah mendapat persetujuan dari Komisi Etik
Penelitian Kesehatan FK USU.

Penelitian ini dilakukan terhadap pasien penyakit PKyang memenuhi kriteriainklusi, yaitu penderita pneumonia komunitas berdasarkan gejala klinis dan juga radiologik sesuai dengan diagnosis pneumonia, baik wanita maupun pria berusia 18 tahun ke atas. Kriteria eksklusi dalam penelitian ini adalah wanita hamil, pada saat 6 bulan postpartum, baru pulang dari rumah sakit 10 hari yang lalu, penyakit ginjal kronik tahap akhir yang menjalani hemodialisis, mendapat terapi antibiotik selama 48 jam terakhir, mendapat terapi heparin dan AT-III, serta pasien dengan gangguan defisiensi AT-III.

Subjek penelitian mengisi lembar persetujuan ikut di dalam penelitian (informed consent), selanjutnya dilakukan pengukuran tekanan darah (TD), laju pernapasan (respiratory rate), denyut nadi, suhu badan, pemeriksaan rontgen dada, serta pemeriksaan laboratorium awal berupa pemeriksaaan darah rutin, fungsi ginjal, biakan darah/ST, biakan sputum/ST, dan AT-III. Kemudian, dinilai derajat keparahan pneumonia komunitas berdasarkan atas skor CURB-65 lalu dihubungkan dengan nilai AT-III.

Data yang diperoleh diolah melalui program SPSS versi 15 for windows. Uji normalitas sebaran sampel menggunakan uji Kolmogorov Smirnov. Untuk melihat hubungan derajat keparahan PK dengan skor CURB-65 terhadap nilai AT-III digunakan korelasi Spearman.

Uji $T$ independent dipergunakan untuk dapat membandingkan variabel nilai AT-III rata-rata antara subjek penderita PK yang sepsis dan nonsepsis yang berdistribusi normal. Untuk

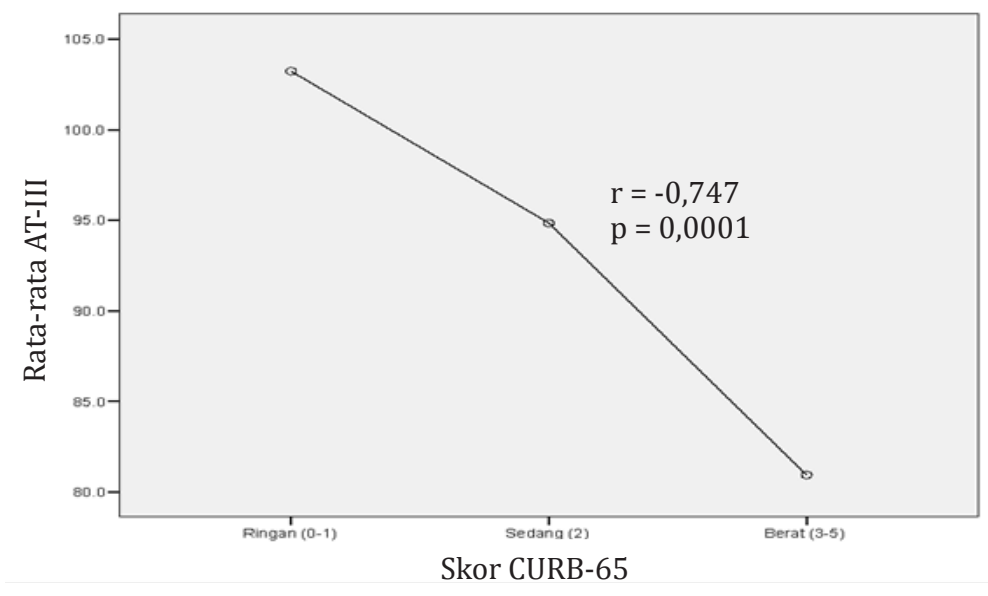

Gambar Korelasi antara Skor CURB-65 dan AT-III 
Tabel 1 Karakteristik Subjek dengan Pneumonia Komunitas

\begin{tabular}{|c|c|}
\hline Variabel & Jumlah \\
\hline \multicolumn{2}{|l|}{ Jenis kelamin (n);(\%) } \\
\hline Pria & $28(51 \%)$ \\
\hline Wanita & 27 (49\%) \\
\hline Usia (tahun) (mean \pm SD) & $52,8 \pm 16,19$ \\
\hline \multicolumn{2}{|l|}{ Tanda vital (mean \pm SD) } \\
\hline Tekanan darah sistol (mmHg) & $108 \pm 10,784$ \\
\hline Tekanan darah diastol (mmHg) & $68,18 \pm 6,96$ \\
\hline HR (kali/menit) & $96,07 \pm 8,63$ \\
\hline RR (kali/menit) & $29,53 \pm 1,72$ \\
\hline Temperatur (Celcius) & $37,98 \pm 0,42$ \\
\hline \multicolumn{2}{|l|}{ Laboratorium } \\
\hline $\mathrm{Hb}(\mathrm{g} / \mathrm{dL})($ mean $\pm \mathrm{SD})$ & $10,45 \pm 2,5$ \\
\hline Leukosit $\left(/ \mathrm{mm}^{3}\right)($ mean $\pm \mathrm{SD})$ & $13.634,7 \pm 5.770,7$ \\
\hline Ureum (mg/dL) (mean \pm SD) & $48,03 \pm 47,69$ \\
\hline Kreatinin (mg/dL) (mean \pm SD) & $1,6 \pm 2,4$ \\
\hline Antitrombin III (AT-III) n (\%) & $91,3 \pm 13,89$ \\
\hline \multicolumn{2}{|l|}{ Skor CURB-65 (n;\%) } \\
\hline Ringan (0-1) & $15(27 \%)$ \\
\hline Sedang (2) & $17(31 \%)$ \\
\hline Berat (3-5) & $23(42 \%)$ \\
\hline \multicolumn{2}{|l|}{ Kultur sputum } \\
\hline Positif & $4(7 \%)$ \\
\hline Negatif & $5(9 \%)$ \\
\hline Total $(n ; \%)$ & $9(16 \%)$ \\
\hline \multicolumn{2}{|l|}{ Kultur darah } \\
\hline Positif & $3(6 \%)$ \\
\hline Negatif & $17(31 \%)$ \\
\hline Total (n;\%) & $20(36 \%)$ \\
\hline
\end{tabular}

semua uji statistik $(\mathrm{p}<0,05)$ dianggap bermakna dalam statistik.

\section{Hasil}

Terdapat 55 orang pasien yang memenuhi kriteria inklusi. Subjek berjenis kelamin pria sebanyak 28 (51\%) dan berjenis kelamin wanita sebanyak 27 (49\%) orang dengan rentang usia 24-76 tahun dan rata-rata $( \pm S D)$ adalah $52,8 \pm 16,19$ tahun. Karakteristik klinis, laboratorium, dan tingkatan skor CURB-65 pasien disimpulkan pada Tabel 1.
Subjek yang tergolong dalam skor CURB-65 berat sebanyak 23 orang (42\%), skor sedang sebanyak 17 (31\%), dan skor ringan sebanyak 15 orang $(27 \%)$. Setelah dilakukan uji korelasi Spearman diperoleh hubungan koefisien korelasi linier negatif $(r=-0,747)$ signifikan antara derajat skor CURB-65 dan penurunan nilai AT-III, ( $p=0,0001$; Gambar 1).

Juga didapatkan nilai AT-III rata-rata semakin menurun sesuai dengan semakin memberatnya skor CURB-65 (Tabel 2). Setelah itu, dilakukan perbandingan nilai AT-III rata-rata antara subjek penderita PK yang sepsis dan nonsepsis 
Tabel 2 Nilai AT-III Rata-rata terhadap Skor CURB-65

\begin{tabular}{lllccc}
\hline & \multicolumn{1}{c}{ CURB-65 } & n & Mean & SD & SE \\
\cline { 2 - 6 } Nilai & Ringan (0-1) & 15 & 103,227 & 1,69 & 0,43 \\
AT-III & Sedang (2) & 17 & 94.841 & 7,06 & 1,71 \\
& Berat (3-5) & 23 & 80.926 & 14,72 & 3,07 \\
\hline
\end{tabular}

diperoleh hasil perbedaan yang signifikan, $(\mathrm{p}=0,001$; Tabel 3).

\section{Pembahasan}

Pada penelitian ini dihubungkan skor CURB65 dengan AT-III saat awal pasien masuk rumah sakit. Hasil penelitian ini didapatkan korelasi signifikan secara statistik dengan uji Spearman antara skor CURB-65 dan nilai ATIII dengan koefisien linier negatif $(\mathrm{r}=-0,747$; $\mathrm{p}=0,0001$ ). Temuan ini menyatakan hubungan yang signifikan antara nilai AT-III dan derajat keparahan PK; semakin meningkat skor CURB65 semakin rendah nilai AT-III yang sesuai dengan penelitian sebelumnya oleh Agapakis dkk. ${ }^{11}$ Selain itu, semakin buruk prognosis penderita PK maka semakin rendah nilai ATIII yang diperoleh dan keadaan ini sudah dapat diperkirakan sejak awal pasien masuk.

Pada penelitian yang dilakukan Agapakis dkk. ${ }^{11}$ menunjukkan penurunan nilai AT- III terhadap derajat keparahan PK; nilai AT-III terlihat menurun pada derajat PK berat dengan nilai $\mathrm{p}<0,001$. Dari penelitian ini juga dijumpai nilai AT-III rata-rata yang rendah sesuai dengan memberatnya derajat keparahan PK yang dinilai berdasarkan skor CURB-65. Pada skor ringan (0-1): $103,227 \pm 1,69$; skor sedang (2): $94,841 \pm 7,06$; skor berat (3): 80,926 $\pm 14,72$. Hal ini menunjukkan bahwa nilai AT-III menurun sejalan dengan memberatnya skor CURB-65.

Pada penelitian ini didapatkan nilai AT-III rata-rata signifikan lebih rendah pada kelompok penderita PK sepsis $(86,413 \pm 15,14)$ dibanding dengan kelompok nonsepsis $(98,12 \pm 8,23)$ dengan uji $\mathrm{T}$ independent $(\mathrm{p}=0,001)$ yang sesuai dengan penelitian sebelumnya oleh Fourrier dkk., ${ }^{13}$ Pettila dkk., ${ }^{14}$ dan Asfhari dkk. ${ }^{15}$ yang menunjukkan rendahnya konsentrasi nilai ATIII pada keadaaan sepsis dan ini sejalan dengan berat keparahan penyakit.

Pada penelitian ini juga menelusuri kultur sputum dan kultur darah untuk mendapatkan kuman penyebab. Dari semua subjek hanya 16\% berhasil didapatkan kultur sputum. Hal ini disebabkan pasien yang pulang sebelum kultur sputum dilakukan dan faktor-faktor lain seperti cara pengambilan dan pengiriman sputum yang kurang representatif, serta sulitnya mendapatkan spesimen sputum. Pada 7\% kultur sputum positif didapatkan empat bakteri yang terdeteksi antara lain Klebsiella pneumoniae, Providencia rettgeri, dan Dermacoccus nishinomiyaensis.

Dari penelitian ini juga didapatkan hasil kultur darah positif hanya 6\%. Pada temuan didapatkan tiga bakteri yang terdeteksi, yaitu kuman Klebsiella pneumoniae, Pseudomonas $\mathrm{sp}$, dan Staphylococcus epidermidis. Baik dari pemeriksaan kultur sputum dan darah tidak ditemukan kuman Streptococcus pneumoniae yang paling umum ditemukan. Hal ini disebabkan oleh jumlah sampel baik kultur sputum dan darah yang masih kurang pada penelitian ini yang memungkinkan temuan kuman patogen pada penelitian ini berbeda dengan kumankuman patogen penyebab PK yang secara umum banyak disebabkan oleh bakteri gram positif sesuai dengan IDSA dan ATS (2007) serta BTS (2009).

Kelemahan pada penelitian ini ternyata jumlah sampel kultur sputum kurang untuk mendapatkan kuman sebagai penyebab sehingga kurang dapat mengambarkan penyebab kuman terbanyak pada penelitian ini. Jumlah sampel kultur darah yang masih kurang belum dapat mengetahui hubungan antara nilai AT-III ratarata dan kultur darah.

Simpulan, bahwa AT-III merupakan biomarker koagulasi yang mempunyai hubungan dengan derajat keparahan PK yang dinilai dengan skor CURB-65 sehingga AT-III dapat digunakan untuk menentukan prognosis pasien PK sejak awal

Tabel 3 Nilai AT-III Rata-rata pada Penderita PK yang Sepsis dan Nonsepsis

\begin{tabular}{llllll}
\hline & CURB-65 & n & Mean & SD & SE \\
\hline \multirow{2}{*}{ AT-III (\%) } & PK (sepsis) & 32 & 86,41 & 15,14 & 2,67 \\
& Non sepsis & 23 & 98,12 & 8,23 & 1,71 \\
\hline
\end{tabular}


masuk rumah sakit. Nilai AT-III yang rendah pada penderita sepsis memberi keyakinan klinisi akan infeksi bakteri sehingga dapat membantu klinisi untuk memutuskan pemberian antibiotik tanpa harus berpedoman pada jumlah leukosit ataupun hasil kultur.

\section{Daftar Pustaka}

1. Hoyert $\mathrm{D}, \mathrm{Xu}$ J. Centers for disease control and prevention national center for health statistics national vital statistics system deaths. National Vital Statistics Reports. 2011;61(6):1-56.

2. De Frances CJ, Lucas CA, Buie VC, Golosinskiy A. National Hospital Discharge Survey. National Health Statistic Reports. 2008;5:120.

3. Dahlan Z. Pneumonia. Dalam: Sudoyo AW, Setiyohadi B, Alwi I, Simadibrata M, Setiati $\mathrm{S}$, penyunting. Buku ajar ilmu penyakit dalam. Edisi ke-5. Jakarta: Pusat Penerbitan Departemen Ilmu Penyakit Dalam FK UI; 2009. hlm. 2196-205.

4. Abidin A, penyunting. Naskah lengkap $11^{\text {th }}$ Annual Scientific Meeting Internal Medicine 2010. Semarang: Badan Penerbit USU Press; 2010.

5. Capelastegui A, Espana PP, Quintana JM, Arcitio I, Gorondo I,Egurolla M, dkk. Validation of predictive rule for the management of community acquired pneumonia. Eur Respir J. 2006;27(1):151-7.

6. Christ-Crain M, Opal SM. Clinical review: the role of biomarkers in the diagnosis and management of community acquired pneumonia. Crit Care. 2010;14(1):1-11.

7. Mira JP, Max A, Burgel PR. The role of biomarker in community acquired pneumonia: prediciting mortality and response to adjunctive therapy. Crit Care. 2008;12(Suppl 6):S1-7.

8. Kaplan V, Clermont G, Griffin MF, Kasal J, Watson RS, Linde-Zwirble WT, dkk. Pneumonia: still the oldman's friend. Arch Intern Med. 2003;163:317-23.

9. Milbrandt EB, Reade MC, Lee MJ, Shook SL, Angus DC, Kong L, dkk. Prevalence and significance of coagulation abnormalities in community acquired pneumonia. Molecular Med. 2009;15(11-12):438-45.

10. Abraham E. Coagulation abnormalities in acute lung injury and sepsis. Am J Respir. Cell Mol Biol. 2000;22(4):401-4.

11. Agapakis DI, Tsantilas D, Psarris P, Massa EV, Kotsaftis P, Tziomalos K, dkk. Coagulation and inflammation biomarkers may help predict the severity of community-acquired pneumonia. Respirology. 2010;15(5):796803.

12. Nimah M, Brilli RJ. Coagulation dysfunction in sepsis and multiple organ system failure. Crit Care Clin. 2003;19(3):441-58.

13. Fourreir F, Chopin C, Goudemand J, Hendrycx S, Caron C, Rime A, dkk. Septic shock, multiple organ failure and disseminated intravascular coagulation compared pattern of antithrombin III, protein $\mathrm{C}$ and protein $\mathrm{S}$ deficiencies. Chest. 1992;101:816-23.

14. Pettilä V, Pentti J, Pettilä M, Takkunen O, Jousela I. Predictive value of antithrombin III and serum c-reactive protein concentration in critically ill patients with suspected sepsis. Crit Care Med. 2002;30(2):271-5.

15. Asfhari A, Wetterslev J, Brok J, Moller A. Antithrombin III in critically ill patients: systematic review with meta-analysis and trial sequential analysis. BMJ. 2007;335 (7632):1-9. 